a concentration of 0.025 per cent of acetylcholine, the increase in enzyme activity by calcium and magnesium amounts to $100-150$ per cent, the inhibition by potassium to about 40 per cent. The inhibition by potassium ions is abolished by calcium or magnesium. In a balanced medium, such as Tyrode solution, a decrease in calcium or magnesium has the same effect on esterase activity as an increase in potassium ions. All these effects are brought about by physiological concentrations of the electrolytes. The following table illustrates these fucts. H I SDROLYSIS OF ACETrLCHOLINE.

0.05 c.c. purifled cholinesterase preparation from horse serum; 0.5 mgm. acetylcholine; 2 c.c. 0.025 mol. sodium bicarbonate; 5 per cent carbon dioxide in nitrogen; $37^{\circ} \mathrm{C}$.

Cations added
(in form of chlorides)

$0.2+\mathrm{mgm} . \% \mathrm{Mg}$

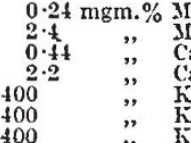

$+0.55 \mathrm{mom} \% \mathrm{Ca}$

Acctylcholine hydrolysed in 3 minutes $124 \gamma$

174

$249 \%$

$283 \gamma$

$73 \gamma$

$133 \gamma$

The adjuvant actions of potassium on parasympathetic effects and the depressant actions of calcium (and magnesium) on such effects may be explained by the effects of these electrolytes on cholinesterase. Potassium, by inhibiting the esterase activity, would delay the destruction of acetylcholine and thus augment parasympathomimetic effects ; calcium and magnesium, on the other hand, by activating the esterase, would accelerate the hydrolysis of acetylcholine, and thus antagonize such effects.

In the same way, the hyper-irritability in the various forms of tetany, known to be associated with a low calcium or magnesium lovel, may possibly be due to a delayed destruction of the acetylcholine liberated by a motor nerve impulse at the nerve endings. The vasodilatation, observed in magnesium deficiency, may similarly bo duo to delayed destruc. tion of acetylcholine liberated by impulses in chol. inergic vasodilator nerves.

\author{
Department of Medical Research, \\ Banting Institute, \\ University of Toronto. \\ July 6.
}

Bruno Mendel.

DOROTHY MUNDELL. Frida Strelitz.

\section{Can Rusts Fix Nitrogen?}

Caldwell et al. ${ }^{1}$ and Murphy ${ }^{2}$ have shown that in wheat and oat plants infected with Puccinia triticina and $P$. coronata respectively, the amount of nitrogen, and of some other substances present, is greater than in uninfected plants. Gretschushnikoff ${ }^{3}$ found that the rust he studied oxcreted urea and ammonia, which, he suggested, were removed by the host, since no correlation was found between the severity of the infection and the amount of ammonia and urea in the extracts of the rusted leaves. Theso facts suggest that rusts may fix atmospheric nitrogen just as some other fungi are believed to do.

Work begun in Cambridge in 1937 and continued in Portugal has suggested that the problem is worth investignting in some detail. The results of two experiments aro given below. Six samples each of fifty plants of Jenkin wheat were grown on sand until the plants were showing the second leaf, and after cutting off the roots and grain the plants were washed in distilled water. Samples 1 and 2 were taken at the beginning of the experiment; samples 3 and 4 were placed with their cut ends in water and kept rust free; samples 5 and 6 were placed in water and inoculated with $P$. graminis tritici, race 27. Sample 4 was accidentally destroyed before the close of the experiment. Samples 3, 5 and 6 wero collected twelve days after the experiment was begun. The plants when collected were dried and then analysed. Tho results of the analyses aro given in the accompanying table.

\begin{tabular}{|c|c|c|c|}
\hline . & Rust-free & $\begin{array}{l}\text { Dry weight } \\
\text { in gm. }\end{array}$ & $\begin{array}{c}\text { Absolute } \\
\text { nitrogen } \\
\text { per gm. }\end{array}$ \\
\hline \multirow[t]{2}{*}{$\begin{array}{l}\text { Initial control } \\
\text { Final control }\end{array}$} & $\begin{array}{l}1 \\
\frac{2}{3}\end{array}$ & $\begin{array}{l}1.2549 \\
1.2558 \\
1.6790\end{array}$ & $\begin{array}{l}0.06504 \\
0.06033 \\
0.06230\end{array}$ \\
\hline & $\begin{array}{c}\text { Inoculated } \\
5 \\
6\end{array}$ & $\begin{array}{l}1 \cdot 5615 \\
1 \cdot 4406\end{array}$ & $\begin{array}{l}0.07335 \\
0.07950\end{array}$ \\
\hline
\end{tabular}

In tho second experiment, seedlings of Spratt Archer barley wero used. Tho seedlings wero prepared in the way described above; fifty plants were dried for analysis when the experiment was begun. Two samples of 225 plants each wero placed with their cut ends in modified Crone's nitrogen-free solution. One sample was kept rust free, tho other was infected with Puccinia anomala raco 12 . Fifty seedlings wero taken every three days from each samplo and dried at once. After twelve days the experiment was discontinued and the samples analysed. The results of the analyses are given below :

\begin{tabular}{|c|c|c|c|}
\hline & & $\begin{array}{l}\text { Dry weight } \\
\text { in } \mathrm{gm} \text {. }\end{array}$ & $\begin{array}{l}\text { Absolute } \\
\text { nitrogen } \\
\text { in gm. }\end{array}$ \\
\hline & $\begin{array}{l}\text { Initial } \\
\text { control }\end{array}$ & 0.7206 & 0.03012 \\
\hline & Rust-free & & \\
\hline \multirow[t]{2}{*}{$\begin{array}{l}\text { No. of days the scedlings } \\
\text { were kept in the solution }\end{array}$} & $\begin{array}{r}.3 \\
6 \\
9 \\
.12\end{array}$ & $\begin{array}{l}0.8353 \\
0.9903 \\
1.0067 \\
1.8007\end{array}$ & $\begin{array}{l}0.0326 \\
0 \cdot 03073 \\
0.0326 \\
0.02996\end{array}$ \\
\hline & Inoculated & & \\
\hline $\begin{array}{l}\text { No. of days the secdlings } \\
\text { were kept in the solution }\end{array}$ & $\begin{array}{r}3 \\
6 \\
9 \\
12\end{array}$ & $\begin{array}{l}0.9156 \\
1.1150 \\
0.9922 \\
0.8336\end{array}$ & $\begin{array}{l}0.033015 \\
0.03458 \\
0.03542 \\
0.04509\end{array}$ \\
\hline
\end{tabular}

The results of other experiments not given here agreo in essentials with those quoted above, although in somo experiments with $P$. glumarum the apparent increase in nitrogen content was not so marked. Irregular results were found with other rusts, particularly if the leaves remained wilted for long periods after inoculation. Nevertheless the experiments point to an increase in the amount of nitrogen in the rustinfected plants.

I realizo the difficulties involved in demonstrating nitrogen fixation by an obligate parasite, yet I feel that the above results are sufficiently suggestive to warrant their being brought to the notice of other workers.

Estação Agronomica Nacional,

Braxquinio d'Oliveira.

Belem, Lisbon. July 5.

${ }^{2}$ Caldwell, Craybill, Sullivan and Compton, J. Agric. Res., 48, 10491071 (1934).

2 Murphy, H. C., Phytopath., 26, 220-23t (1936).

3 Gretschushnikoff, A. I., C.R. Acad. Sci. U.R.S.S., N.S., 2, 33j-310 (1936); (Ref. in Rer. Appl. inycol., 15, 710; 1936). 